\title{
Socioemotional Wealth and Corporate Social Responsibility: A Critical Analysis
}

\author{
Piotr Zientara ${ }^{1}$
}

Received: 4 March 2015 / Accepted: 31 August 2015/Published online: 5 September 2015

(C) The Author(s) 2015. This article is published with open access at Springerlink.com

\begin{abstract}
This theoretical paper is offered in the spirit of advancing the debate on the socioemotional wealth (SEW) construct and its impact on how family firms conceptualize and practise corporate social responsibility (CSR). The study builds on Kellermanns et al.'s (Entrep Theory Pract 36(6):1175-1182, 2012) claim that the SEW dimensions can be positively and negatively valenced as well as makes a distinction between the selective and instrumental approach to CSR and the holistic and normative one. Drawing on these considerations, it provides a theoretical underpinning in favour of the view that SEW has ambivalent nature and therefore can produce detrimental outcomes for stakeholders of family companies. In this way, the study challenges the implicit assumption prevalent in the literature that SEW is "a prosocial and positive stimulus". Crucially, it expands on the SEW construct by arguing that, given its ambivalent nature, SEW, as such, is at odds with the "strategic, whole-business view of responsibility". Consequently, it posits that family firmsbecause of their concern with SEW - may be more likely to adopt the instrumental and selective rather than strategic (holistic) and normative approach. Hence, it also makes the case for regarding the latter as a reference point to investigate the family company's attitude towards social responsibility. It concludes by summarising the argument and offering future research avenues.
\end{abstract}

Piotr Zientara

zientara@fest.pl

1 Department of Economics, University of Gdansk, 119/121 Armii Krajowej Street, 81-824 Sopot, Poland
Keywords Socioemotional wealth $\cdot$ Corporate social responsibility · Family firms · Human resource management $\cdot$ Environmental management
Abbreviations
CSR Corporate social responsibility
EM Environmental management
HRM Human resource management
SEW Socioemotional wealth

\section{Introduction}

Much consideration has of late been given to the problematics of corporate social responsibility (CSR), which has not only emerged as an influential managerial concept, but has also entered the public discourse, influencing the debate on the role of the company in today's society (Baron 2001; Blowfield and Murray 2011; Chandler and Werther 2014; Economist 2014a; Lim and Tsutsui 2012; Porter and Kramer 2006, 2011). Therefore, extensive multidisciplinary research has been undertaken-within the theoretical framework that combines business ethics, strategic management and behavioural economics-into the motives, mechanisms and effects of the adoption of socially responsible practices (see, inter alia, Aguilera et al. 2007; Hillenbrand et al. 2013; Zientara et al. 2015).

Within the family business literature, the discussion has been framed around the question of whether family firms are more socially responsible than their non-family counterparts (Adams et al. 1996; Bingham et al. 2011; Cennamo et al. 2012; Dyer and Whetten 2006; Cruz et al. 2014; Morck and Yeung 2003; Stavrou et al. 2007; O'Boyle et al. 2010). Without a doubt, family firms differ in some 
respects from non-family enterprises (Chrisman et al. 2012; Chua et al. 2009; Sharma 2006). Above all, they are characterized by the need to protect and preserve socioemotional wealth (SEW) - a multidimensional construct that denotes family owners" "affective endowments" (Berrone et al. 2012b). By and large, the particular SEW dimensions-family control and influence, identification of family members with the firm, binding social ties, emotional attachment to the firm and renewal of family bonds-are "portrayed as inspiration for family firms to demonstrate care for their stakeholders. As such, SEW is depicted as a prosocial and positive stimulus" (Kellermanns et al. 2012, p. 1176). This is all the more so given that "members of family firms are more likely to view the business as an extension of themselves. As a result, they are more likely to avoid situations that may bring negative perceptions to their organizations" (O'Boyle et al. 2010, p. 4). All this has led many scholars (Cennamo et al. 2012; Cruz et al. 2014) to assume that family businesses may well be more inclined to engage in CSR than non-family firms (however, the findings by Morck and Yeung (2003) do not bear this assumption out).

Of course, family firms themselves do not constitute a homogenous group in terms of CSR adoption (Déniz-Déniz and Cabrera-Suárez 2005). For example, a study by Marques et al. (2014) shows that Spanish family enterprises follow different patterns of engagement in CSR, with family values being a key differentiating factor. This strand of research, rather than investigating whether family firms are more or less socially responsible than non-family ones, seeks to explore the mechanisms that underlie family firms' attitudes towards CSR. In other words, what is at issue here are the particular factors that determine the family firm's inclination to engage in CSR. And chief among them is family involvement, which is instrumental in embedding family values into the organisational culture. And research shows that those firms that are characterized by greater family involvement are also more likely to engage in CSR (Bingham et al. 2011; Gedajlovic et al. 2012; Marques et al. 2014; O'Boyle et al. 2010).

Nonetheless, if one assumes that SEW is the main frame of reference for family firms, its protection and preservation must also be seen as playing a key role in how family companies conceptualize and practise CSR. Given that CSR is conceptually embedded in the stakeholder view (Freeman 1984), it matters how SEW protection affects treatment of different stakeholders. In this context, Berrone et al. (2012a) argue that, in a bid to preserve SEW, family owners carry out proactive stakeholder engagement (PSE) initiatives underpinned by either instrumental or normative motives. Likewise, Cruz et al. (2014), focusing explicitly on CSR, assert that family owners, being primarily concerned with SEW protection, vary in their responses to the demands of different stakeholders. Pertinently, they found that (Spanish) family enterprises tend to behave responsibly towards external stakeholders and, at the same time, irresponsibly towards internal stakeholders. This, in turn, led them to postulate that family firms "can be socially responsible and irresponsible at the same time" or, in other words, can simultaneously be "good and bad" (Cruz et al. 2014, pp. 1295-1296).

Admittedly, such discriminatory behaviour can also be observed in non-family firms, which sometimes treat differently internal and external stakeholders, too. Still, it is family firms that, at least in theory, are more likely to act in this way due to SEW (in particular, due to the "family control and influence" dimension of SEW). Indeed, as Kellermanns et al. (2012) argue, SEW may have a "dark side" and, accordingly, produce negative outcomes for stakeholders of family firms. This is because, to follow their reasoning, the particular dimensions of SEW can be positively and negatively valenced, which, as such, is at variance with the view prevalent in the literature (Berrone et al. 2012a, b) that the SEW dimensions have positive valence (see also Barrett 1996). It follows that SEW may also a key factor behind the family's self-serving conduct (Kellermanns et al. 2012). These insights have serious implications for the practice of CSR in family firms.

Indeed, being "simultaneously socially responsible and irresponsible" bears upon the very essence of CSR, which centres on a much-debated dichotomy between normative and instrumental motivation for CSR adoption. Apart from purely ethical concerns that also raises questions about the costs of CSR adoption and its impact on corporate performance (Lee 2008). In this context, much has been made of "shared value" - a sort of win-win outcome whereby both the company and the environment benefit as reduced resource consumption, thanks to the introduction of environmental management practices, results in lower operating costs and hence smaller environmental impacts (see also Porter and Kramer 2011). From a certain perspective, however, such attitude towards CSR hallmarks instrumental motivation: after all, it is in any company's interest to produce efficiency gains by cutting resource consumption (irrespective of the impact on the environment) and subsequently to publicize its achievements in order to burnish its green (and philanthropic) credentials for the sake of image and reputation.

However, there is evidence that a growing number of companies have come to regard CSR as an holistic business philosophy (or a management ethos). Accordingly, for those firms CSR becomes a core part of their strategy (Bohdanowicz and Zientara 2008; Coles et al. 2013; Camilleri 2014), which means that it underpins entire business practice and serves to set "targets not only for the company but for the people it works with and sells to" 
(Economist, 2014a, p. 53). In the words of Coles et al. (2013, p. 126), "the practice of CSR within organisations [...] should not be selective. For instance, it should not focus exclusively on a single issue domain such as the environmental impacts of an organisation. [...] It involves a strategic, whole-business view of responsibility that is expected to permeate all areas of operations, across the entire value chain, and with due consideration of the distinctive needs of stakeholder groups" [my italics]. All this implies a strategic approach of holistic character that is underpinned by genuine commitment and normative motivation. By definition, it involves behaving responsibly towards all stakeholders and, consequently, rules out cherry-picking those socially responsible initiatives that are seen to serve narrowly defined company interests (the epitome of self-serving behaviour). Unilever and Scandic can be held up as paragons of this approach (Bohdanowicz and Zientara 2008; Economist 2014a).

In the light of these considerations, it is possible to assume that, because of concern with SEW and its "double-valenced" nature, family owners might be more inclined to adopt the selective and instrumental approach rather than the strategic (holistic) and normative one. To reiterate, for a firm that is authentically committed to CSR, it would be inconceivable, say, to selectively implement environmental management practices $^{1}$ and, at the same time, treat its employees unfairly since such conduct might suggest inconsistency or a kind of "corporate schizophrenia". Put another way, they might be more likely to treat CSR selectively and instrumentally, as a means of obtaining — in the name of SEW — various self-interested "gains" rather than as a centrepiece of the strategy that reflects their authentic and altruistic preoccupation with the wider social good. All that implies that, instead of asking whether family firms are more socially responsible than non-family businesses, it is more appropriate to ask what an approach to CSR they are likely to adopt in view of the ambivalent nature of SEW. The present paper, which is theoretical in character, aims to critically address these issues.

More specifically, this study makes a number of contributions to the extant body of research on SEW and CSR. First, building upon Kellermanns et al.'s (2012) claim that

\footnotetext{
${ }^{1}$ It should also be noted at this juncture that, in practice, two dimensions of CSR - environment and employee (alongside community and customer/product) - overlap with human resource management and environmental management (EM). The former involves practices and functions that seek to attract, develop and retain the organisation's human resources (Lado and Wilson 1994) while the latter involves "the processes and practices introduced by an organization for reducing, eliminating, and ideally, preventing negative environmental impacts arising from its undertakings" (Cooper 1998, p. 112). Alternatively, four CSR dimensions are described as workplace, marketplace, environmental and community CSR.
}

the SEW dimensions can be positively and negatively valenced, it provides a theoretical underpinning in favour of the view that SEW, essentially, has ambiguous nature and can thus produce detrimental outcomes for stakeholders of family companies. Accordingly, the paper challenges the implicit assumption prevalent in the literature that SEW is "a prosocial and positive stimulus" (Berrone et al. 2012a, b). Rather, it argues that SEW-due to its "doublevalenced" nature_can be a negative stimulus, which leads to business practice contradictions that might ultimately threaten the very survival of the firm (thereby risking a total loss of SEW). For example, the paper shows that family owners who seek to burnish their environmental credentials for the sake of the "image and reputation" dimension of SEW and who, at the same time, treat unfairly their own employees due to the "family control and influence" dimension act contradictorily and counterproductively. This is because without voluntary involvement of (low-ranking and non-family) employees, it is virtually unfeasible to carry out any environmental management practices ${ }^{1}$ and because - thanks to public scrutiny of corporate conduct in social media-the family firm's reputation can be tarnished not only by irresponsible behaviour towards external stakeholders (i.e. the environment), but also by irresponsible conduct towards internal stakeholders. At the same time, incompetent or unfair treatment of employees negatively affects the firm's competitiveness, which not only diminishes the family's chances of acquiring tangible socioemotional benefits, but may also result in the total SEW loss. Therefore, by acting like this, the family might end up harming itself (which, from a certain point of view, might be interpreted as "blindness" to the "dark side" of SEW).

Second and related, the paper expands on the SEW construct by arguing that, given its ambivalent nature, SEW, as such, is at odds with the "strategic, whole-business view of responsibility". Consequently, it posits that family firms - because of their concern with SEW-may be more likely to adopt the instrumental and selective rather than holistic and normative approach. Put another way, they might be more likely to treat CSR selectively and instrumentally, as a means of obtaining - in the name of SEW-various self-interested "gains" rather than as a centrepiece of the strategy that reflects their authentic and altruistic preoccupation with the wider social good. It follows that, rather than being a "prosocial stimulus", SEW might well be a driver of self-serving behaviour, which runs counter to the perception of CSR as a force for the wider social good.

Third, by advocating the "whole-business view of responsibility" held by genuinely committed firms, the paper suggests that-given the ambivalent nature of SEW-it is more appropriate to ask what an approach to 
CSR family firms are likely to adopt rather than whether they are more likely to practise CSR relative to non-family businesses. In this way, the paper not only challenges the predominant view that-due to preoccupation with SEW and its apparently prosocial and positive nature-family companies may be more inclined to engage in CSR (O'Boyle et al. 2010; Cennamo et al. 2012), but also makes the case for regarding the holistic and normative approach as a reference point to explore family companies' attitudes towards social responsibility.

Thus, the paper is offered in the spirit of advancing the debate on the SEW construct and its impact on how family firms conceptualize and practise CSR. While building on Kellermanns et al. (2012), it expands on their work by applying their insights into the SEW nature to the problematics of CSR (they focus on proactive stakeholder engagement rather than corporate social responsibility). To the best of my knowledge, there is little research work that, while assuming that the SEW dimensions can be negatively valenced, analyse its implications for CSR practice in family firms. Its structure is as follows. The next sections explore the implications of the double-valenced nature of SEW for the family firm's stakeholders and reputation. Then, the focus shifts to societal values and their role for adoption of the whole-business view of responsibility. The following part discusses SEW in the context of the overlap between the employee dimension of CSR and (green) human resource management. The final section summarises the argument, highlights contributions to the literature and suggests future research directions.

\section{The Implications of the Sew Approach for Stakeholders}

Even though some scholars continue to be critical of corporate social responsibility (Mayer 2013) and decry terminological confusion stemming from the widespread use of overlapping but not completely interchangeable terms (such as "social responsibility", "corporate citizenship" or "corporate responsibility") (Blowfield and Murray 2011), it is widely acknowledged that CSR now occupies an increasingly prominent position in business practice and, at the same time, has an important role to play in solving societal problems (Cacioppe et al. 2008). This is premised on the belief that a company's responsibility lies with stakeholders rather than shareholders (Freeman 1984), implying that it has obligations vis-à-vis society other than the maximisation of shareholder wealth (Font et al. 2012). In fact, CSR directly bears on the stakeholder view and, by extension, on the notion of "stakeholder democracy" (Freeman 1984), according to which firms have not only shareholders, but also different (internal and external) stakeholders, who, as such, are the recipients of corporate actions (Wood and Jones 1995). The implication is that managers, while seeking to maximise shareholder wealth, should not disregard the interests and concerns of their companies' stakeholders (Peterson 2004).

In theory, this holds true of both family firms and their non-family counterparts. Yet in family firms things are more complicated. First, the family is an internal stakeholder on account of its intrinsic links with the firm, such as ownership and control, but non-family employees (with outside managers to the fore) also belong to this category (Mitchell et al. 2011). Hence, a distinction is made between family and non-family internal stakeholders (it follows that, when it comes to family firms, the internal stakeholder category is not a homogenous one). Second and even more important, family enterprises are characterized by the need to preserve SEW, which has profound implications both for stakeholder treatment and CSR practice.

In principle, SEW connotes the emotional value intertwined with the family firm that satisfies the family's affective needs, such as influence and affinity. Therefore, family members are, as a rule, motivated by a desire to protect and preserve SEW (Berrone et al. 2012a, b). For that reason, they are thought to be likely to eschew any action that might imperil SEW, which, at least theoretically, makes family firms more inclined to engage in socially responsible actions. In this context, Berrone et al. (2012a), while exploring the inclination of family owners for proactive stakeholder engagement, argue that, in a bid to preserve SEW, they are driven by instrumental or normative motives - a view that suggests different responses to the claims of different stakeholders. Likewise, Cruz et al. (2014) point out that, when considering engagement in CSR-inspired initiatives, family owners are preoccupied with SEW protection, but-given the multidimensional character of SEWthey are likely to vary in their responses to the demands of different stakeholders. All this implies "stakeholder differentiation" on the part of family owners. In practice, this often means discriminatory behaviour vis-à-vis nonfamily internal stakeholders.

Indeed, there is evidence that favouritism in general and nepotism in particular are commonplace in many family businesses, resulting in non-family employees being discriminated against (Burkart et al. 2003; Jaskiewicz et al. 2013). For instance, non-family employees are often passed over for promotion. If SEW is a reference point, this can be explained away by the "family control and influence" and "emotional attachment" dimensions. By ascribing positive valence to these dimensions, SEW family owners-concerned with SEW preservation-tend to act in such a way so as to exert (permanent) control over the firm's operations (Berrone et al. 2012a, b). This is why they are 
reluctant to hire outside chief executives, to delegate power to non-family managers, to give non-family employees a greater say in how the firm is run and to appoint outsiders to the board (in 2015 the founder of Otsuka Kagu, a Japanese furniture producer, sought to "oust his daughter from the top of the family's firm" for "bringing in outside directors to sit alongside family members on the firm's board; Economist, 2015d, p. 52). Likewise, the "emotional attachment" dimension of SEW implies that many family members perceive their firms as a place where their desiderata of affinity and self-fulfilment coincide and blend. In practice, this underpins differentiation between "us" (family members) and "they" (non-family members) and, by extension, the aforesaid discriminatory conduct vis-à-vis the latter.

But such unfair and irresponsible treatment may produce negative firm-level and employee-level outcomes; thereby suggesting negative valence for these SEW dimensions (Kellermanns et al. 2012). Given that outside managers may not be empowered and/or may not be allowed to participate in organisational decision-making, they are likely to feel that not only are they treated unfairly, but also that their potential (expertise and competence) is underutilised-a sentiment that is bound to render them dissatisfied with their jobs and hence uncommitted to their organisation (Kirkman and Shapiro 2001; Porter et al. 1974). Therefore, from the theoretical perspective combining the resource-based view and HRM thinking, family owners' tendency to retain total control might be seen as a serious weakness that risks affecting their firm's competitiveness and performance (Armstrong 2009; Barney 1991, Barney et al. 2001; Makadok 2001). The Economist (2015a, p. 60), referring to a study by John van Reenen and his colleagues, points out that their "research shows that where family owners plump for outside chief executives, their firms do no worse than similarly sized ones with more diverse shareholders. But all too often they pick kin over professional managersand performance suffers". In this way, the family might end up harming itself.

At this point, it is also useful to draw on stewardship theory, which holds that managers are not always driven by a desire to achieve individual objectives and, accordingly, may well behave as responsible stewards of the resources (assets) they control (Corbetta and Salvato 2004; Davis et al. 1997). This is due to a number of socio-psychological and contextual factors that cause managers to regard themselves as stewards whose "behavior is ordered such that pro-organizational collectivistic behaviours have higher utility than individualistic, self-serving behaviors" (Davis et al. 1997, p. 24). That, in turn, helps align their interests with those of owners, which makes them less likely to act, as agency theory suggests, to the detriment of the latter ${ }^{2}$ (Barney and Hesterly 2008; Chua et al. 2009). But-in view of the "double-valenced" nature of SEW and the resulting discriminatory and irresponsible treatment of non-family internal stakeholders-it seems inconsistent and contradictory to expect non-family managers to eschew selfserving behaviours and, consequently, to act as responsible stewards (of the family firm's assets).

Crucially, this asymmetric stakeholder treatment ("family vs non-family members") also bears on the question of "who we are" as an organisation, thereby invoking the organisational identity theory, which focuses on what is idiosyncratic and lasting about the firm. Given the centrality of the family (and their status of the "privileged" internal stakeholder), some scholars argued in the past that family firms could afford to disregard—or, at least, to be less responsive to-the claims of external stakeholders. Of late, however, this view has been called into question since, given that the identity of the family is inextricably intertwined with that of the firm, in the eyes of external stakeholders both identities fuse into one. In this context, Cruz et al. (2014, p. 1296) state that "because family firms are concerned with their image and reputation as a way to protect their SEW, they are likely to be more responsive to external stakeholders' demands [...] than non-family firms". At the same time, "their concern with control and influence within the company and their strong emotional attachment to it (another two key SEW dimensions) are likely to deter social actions related to internal stakeholders $[\ldots] "$.

In practice, this means that, when it comes to CSR, family firms are likely to behave differently towards internal stakeholders and external stakeholders (see also Mitchell et al. 2011). If follows that family owners, because of their concern with SEW, not only treat differently family and non-family internal stakeholders, but also discriminate between internal and external stakeholders (since, to repeat, the firm is likely to implement chiefly those socially responsible practices that meet the demands of external stakeholders). As a result, it is, in principle, non-family employees who suffer discriminatory behaviour, suggesting negative valence to these SEW dimensions and the consequent (CSR-related) contradictions.

\footnotetext{
This directly concerns the characteristic feature (and strength) of family businesses, namely, that "they solve the 'agency problem' that Adam Smith put his finger on in 'The Wealth of Nations' when he argued that hired managers would never have the same "anxious vigilance' in running companies as the owners" (Economist 2014b, p. 12).
} 


\section{Socioemotional Wealth and Company Reputation}

Above all, it is reasonable to claim that the family image and reputation can also be tarnished by irresponsible behaviour vis-à-vis internal stakeholders (see also Zellweger et al. 2011). In fact, in today's reality, which is increasingly influenced by what people do in social media, any irresponsible behaviour-be it towards internal or external stakeholders-can sully the firm's reputation. Indeed, given that nowadays negative (electronic) word-of-mouth publicity is a mouse click away, it is naïve or irrational to assume that behaving badly towards one's employees can be concealed, and thus somehow unnoticed by the public, even if it is accompanied by socially responsible behaviour towards, say, the environment. Therefore, it is perfectly possible to imagine a situation wherein the family firm treats its nonfamily employees unfairly (thus behaving irresponsibly towards its internal stakeholders), at the same time carrying out green practices or helping the needy in the local community (thus responding to the demands of external stakeholders). Yet, if the former conduct is publicised through social media and if subsequently internet-users spearhead an online campaign against that firm, its image is bound to suffer, no matter how much it does for the environment or the local community (an online campaign on Facebook mounted against Polish employers who behave unfairly and dishonestly towards their workforces is a case in point (Gazeta Wyborcza 2015).

Pertinently, McDonald's provides an example of how unfair and irresponsible treatment of employees can tarnish the reputation of a firm even if, simultaneously, it acts responsibly in other areas of CSR (i.e. the environment, the customer or the community). As is well known, McDonald's has of late gone to great lengths to green its operations (to reduce its environmental footprint) and to ameliorate the wellbeing of its customers (by including healthy products in its traditional menu), implying that the American company might have come closer to adopting the holistic and normative approach to CSR. Yet, in the meantime, McDonald's was accused of flagrant mistreatment of its employees by violating their "rights to campaign for better pay and working conditions" and resorting to "threats, surveillance, discrimination, reduced hours and even sacking of workers who supported the protests" (Economist, 2015b, p. 49). This provoked widespread indignation online and, crucially, demonstrated that the company's approach had, in fact, little to do with the holistic, value-based view of responsibility (at the same time, thwarting its attempts to shed its reputation for unfair if not exploitive staff treatment).

Of course, McDonald's is not a family firm, but the case does show how any company that acts responsibly towards external stakeholders and irresponsibly towards internal ones is likely to end up-thanks to the power of social media and electronic word of mouth - with its reputation tarnished. It also provides a counterexample to the argument that the eponymous family owner, by acting irresponsibly and thus imperilling SEW, has more to lose than "faceless investors" (in a public non-family company, such as McDonald's). In fact, it is safe to assume that nowadays no company-be it a family or non-family one-can afford to behave irresponsibly in any area of its operation as this is bound to be immediately castigated by the online community, with all its negative reputational consequences.

Therefore, those who argue that family firms are particularly concerned with their external image and hence do not want to be perceived as irresponsible corporate citizens by external stakeholders (Cruz et al. 2014; Deephouse and Jaskiewicz 2013) fail to realise that—in line with the above reasoning - today the external image of the family firm is shaped also by internal stakeholders (i.e. employees), who tend to publicize and share their personal impressions and judgements of their employer's behaviour in social media (interestingly, Zellweger et al. (2011) suggest that imageconscious family businesses should focus their CSR efforts on internal stakeholders). It follows that behaving irresponsibly towards its employees can nowadays have an equally damaging effect on the firm's reputation as failure to implement environmental management practices or to help poor inhabitants of the local community.

In the light of these considerations, it is even problematic to differentiate between the "external image" projected to "external stakeholders" (Cruz et al. 2014, p. 1300) and, consistently, the "internal image" projected to "internal stakeholders". Actually, in an era of the internet and social media, it seems more appropriate to speak of a single reputation, which is projected simultaneously to internal and external stakeholders. This means that if the family firm really wants to avoid being stigmatised as an irresponsible corporate citizen with a view to protecting SEW, it needs to endorse corporate social practices related to internal and external stakeholders alike. However, as we already know, family owners, preoccupied with their image and reputation as a way to protect SEW, tend to respond to the needs of the latter, de facto discriminating against the former. Such conduct has two important implications.

First, it undermines the claim that SEW is a "prosocial and positive stimulus". After all, since non-family employees are members of society on a par with inhabitants of local communities and the firm's customers, they deserve, in equal measure, being treated responsibly and fairly. To take the argument to its logical conclusion, SEW can only be seen as "pro-social" if non-family employees are somehow excluded from society, which, obviously, 
makes little sense. This, again, suggests negative valence and contradiction. Second and related, it is at variance with the strategic, whole-business view of responsibility, which, in essence, rules out behaving differently towards internal and external stakeholders and cherry-picking those socially responsible initiatives that are deemed particularly useful (for the promotion of the firm's interests). In line with what has been argued in the introduction, it is fair to say that such selective and discriminatory behaviour amounts to "corporate schizophrenia". And this is exactly what emerges from the study by Cruz et al. (2014, p. 1295) who found that family firms "can be socially responsible and irresponsible at the same time".

Undoubtedly, such "corporate schizophrenia" is not typical of the conduct of authentically committed companies, such as Scandic (Bohdanowicz and Zientara 2008), whose Code of Conduct applies universally to its employees (called team members), suppliers, the environment and local communities (Scandic 2014). This is also true of Hilton Worldwide (Bohdanowicz et al. 2011) - a hotel chain inseparably associated with the Hilton family (albeit no longer a family company). It follows that a firm that adopts socially responsible practices towards external stakeholders and, at the same time, behaves irresponsibly towards internal stakeholders cannot regard CSR as a core value (see also Bohdanowicz and Zientara 2012; Garay and Font 2012; Thornton and Byrd 2013; Zientara 2014). It might be argued, therefore, that, given the imperative to preserve SEW and its ambivalent nature, family firms are likely to adopt the selective and instrumental approach. Accordingly, they tend to view CSR as a mere (public relations) tool-rather than as a core part of the strategywith which to serve the family's (narrowly defined) interests (it follows that well-publicised engagement in deliberately cherry-picked CSR initiatives is perceived as a gain in SEW).

Of course, this issue, which has been brought up earlier, is central to the problematics of CSR and comes down to the following question: is corporate social responsibility, in essence, about doing good for its own sake ("because this is the right thing to do") or about being seen to do good ("because it pays to project the image of a responsible corporate citizen and because it is unbecoming for a company not to practise CSR"). In other words, should one regard CSR as a core value that normatively underpins all corporate decision-making or as a marketing instrument that serves narrowly defined corporate interests (Garay and Font 2012; Holcomb et al. 2007; Kotonen 2009; Rodriguez et al. 2006; Vaaland et al. 2008)? Indeed, it is telling that some scholars who explore CSR in family firms employ such phrases as "obtain reputational benefits" or "firms benefit $[\ldots]$ from the implementation of social practices" (Cruz et al. 2014, p. 1300), which unambiguously implies the instrumental and selective approach and, by extension, self-interest. This, in turn, sits awkwardly with their definition of corporate social responsibility, which-borrowed from McWilliams and Siegel (2001)—states that CSR is about "actions that appear to further the social good, $b e$ yond the interest of the firm" (p. 117) [my italics]. To be consistent, Cruz et al. (2014) should have defined CSR as "actions that appear to further the social good, in the interest of the firm" (the implication is that SEW acts as a driver par excellence of self-serving behaviour).

This aspect directly bears upon the question of the impact of CSR on corporate performance (Lee 2008). Even though it is increasingly argued that holistic and genuine commitment entails a shift towards the concept of triple bottom line, it does not necessarily have to signify that "the virtue is its own reward". In fact, one can imagine a situation in which a company that is authentically committed to CSR raises wages (to reduce income inequality) and ensures that its products are ethically sourced (to improve the situation of the workers who are employed by its subcontractors in low-cost countries), which in the shortterm translates into higher operating costs. Yet, in the meantime, it earns a reputation for integrity and responsibility, which, in turn, attracts socially conscious customers and appeals to like-minded investors (Carvalho et al. 2010; Luo and Bhattacharya 2006). It also helps that its corporate policies change "customers' behaviour in beneficial ways-by, say, increasing demand for green products that the firm makes" (Economist 2014a, p. 53). All this eventually translates, ceteris paribus, into higher profits, which suggests that it is possible to reconcile the corporate good with the social good (Wijesinghe 2014). Nonetheless, there is a world of difference between a decision to behave responsibly because company owners/managers believe that such conduct is likely to result in "reputational gains" (the instrumental and selective approach) and a decision to behave responsibly because one believes that only such conduct is "fundamentally good" and "morally right", irrespective of whether it translates into any gains or not (the holistic and normative approach).

\section{The Role of Societal Values for CSR Practice}

This raises the question of why certain firms decide to wholeheartedly embrace CSR. In fact, such a stance concurrently reflects and emanates from values, which define "what people believe to be fundamentally right or wrong" (Gursoy et al. 2013, p. 41) and, by this token, underpin the collective psyche. In this context, it has to be emphasised that, over the last two decades, there has been a significant shift in how developed societies perceive not only the role of the firm in the capitalist system, but also capitalism itself 
(even if one allows for the existence of different versions of capitalism across the world). The emergence of spontaneous, grass-roots protest movements, such as Occupy Wall Street, Anonymous or Spanish Indignados-alongside numerous non-governmental organisations seeking to fight against all sorts of societal injustices and abuses-is a reflection of that shift.

Since more and more people realise that devastating the environment and exploiting workers (be it directly or indirectly employed) is morally wrong and unacceptable, they set much store on environmentalism and equity of treatment in the workplace (Zientara 2014). This, in turn, leads them to expect companies to behave responsibly visà-vis the environment and their workforces and-given that most members of society are both customers and employees-to "punish" those firms that act irresponsibly. That can be done, apart from spreading negative (electronic) word of mouth, by boycotting their products or ruling them out as potential employers - a choice that is fraught with serious consequences for any company willing to hire talented and motivated individuals (Albinger and Freeman 2000; Cacioppe et al. 2008; Greening and Turban 2000). Cacioppe et al. (2008) argue in this context that well-educated managers and professionals tend to take into account "the ethical and social responsibility reputations of companies when deciding whether to work for them, use their services or buy shares in their companies" (p. 681). And in an era of the global war for talent, no firm can afford to forgo employment of socially conscious high skilled persons. Equally importantly, there is strong evidence that the firm's engagement in CSR is positively associated with employees' attitudes, most notably with their organisational commitment (Stites and Michael 2011, Zientara et al. 2015). Thus, a company that acts irresponsibly risks seeing some of its employees leave or engage insufficiently in their work, which is likely to undermine its competitiveness (of which more below).

But, certainly, employers (firm owners/managers) are also members of society. The implication is that if they espouse and internalise the same values-in other words, if they believe, like others, that behaving irresponsibly towards the environment and the workforce is morally wrong-they are more likely to put these ideals into practice in their companies. This has special significance for family firms. Given that it is family involvement that determines-through the values the family cherishes and lives by-the family firm's engagement in CSR (Marques et al. 2014), it is reasonable to assume that if the family owner strongly believes in environmental sustainability and social fairness, he or she can easily turn these ideals into a reality due to the control they exert over the firm. That may also partially explain why family firms are more likely to engage in CSR than their non-family counterparts.
However, as has been argued throughout the paper, the question is not whether they are more likely (than nonfamily companies) to implement CSR initiatives, but what an approach to CSR they are likely to adopt. This is because, to follow the above line of argument, their preoccupation with SEW can lead them to embrace the instrumental and selective approach, which, as such, is worlds apart from the holistic and normative approach.

Regardless of the family context, it is fair to say that, values per se go a long way towards explaining why some firms decide to hold a strategic, whole-business view of responsibility. Arguably, it is Scandinavia that provides compelling evidence in favour of this postulate. There is little doubt that in Sweden, Norway, Finland, Iceland and Denmark people are not only emotionally attached to environmentalism, social fairness and egalitarianism, but also "practise what they preach". Indeed, Scandinavians are renowned for their environmental attitudes and environmental responsible behaviour (ERB) (see also Lee et al. 2015). Not coincidentally, in Scandinavia "veneer environmentalism" - or the gap between the professed environmental values and the actual behaviours (Scott 2011; Weaver 2011) - is less prevalent than elsewhere in the world. Furthermore, as citizens and members of society, they expect governments to enact and enforce relevant legislation (Albrizio et al. 2014; Environmental Performance Index 2015), as customers and employees, exhibit a strong preference for firms that behave responsibly and, as employers, ensure the realisation of these ideals in the workplace. Norway, for example, has made greatest strides towards gender equality, introducing female-friendly policies that encompass board quotas and public child care.

It is no coincidence, too, that a considerable number of Scandinavian companies have decided to espouse a strategic, whole-business view of responsibility (Bohdanowicz and Zientara 2008; Kotonen 2009; Coles et at. 2013). This means, to repeat, that they see CSR as a core part of their strategies and, accordingly, behave responsibly not because they seek to "obtain reputational gains", but because they believe that irresponsible behaviour-both towards internal and external stakeholders-is "fundamentally wrong and morally unacceptable" (Scandic 2014).

\section{Sew in the Context of the Overlap Between Hrm and the Employee Dimension of CSR}

The above quotation from Scandic's Code of Conduct suggests that family firms' tendency to abate social practices directed at internal stakeholders (i.e. non-family employees) not only goes against the holistic approach, but also flies in the face of modern HRM thinking (Armstrong 
2009; Guest 1997; Lado and Wilson 1994). This is because it is in the very interest of any organisation to treat its employees well, regardless of whether it is committed to CSR or not and whether it is a family firm or not (De Kok et al. 2006). If, to follow this reasoning, the firm mismanages its employees-or if it fails to develop their potential (via training), to treat them fairly (via pay and promotion based on merit rather than connections or family ties), to involve them in organisational decision-making (via participation and empowerment) or to unfetter their creativity (via autonomy and a supportive organisational climate)-it is likely to see, ceteris paribus, its competitiveness decrease. As Collins and Smith (2006) suggest, HR systems "affect firm performance by creating an organizational environment that elicits employee behaviours and capabilities that contribute to firm competitive advantage" (p. 545). Accordingly, neglect of HRMwhich is likely to produce an uncommitted and untrained workforce-seems to be self-defeating.

What it comes down to, therefore, is that incompetent HRM-especially, paying scant regard to high-performance work systems (HPWS), which "refer to a group of separate but interconnected HRM practices [...], which are designed to enhance employee and firm performance outcomes through improving workforce competence, attitudes, and motivation" (Takeuchi et al. 2009, p. 1)—can affect the firm's ability to compete and ultimately to survive. ${ }^{3}$ And, as is widely acknowledged, family firm failure is associated with the total SEW loss; in extremis, the family loses everything if its firm goes under. That, in turn, prompts the (pragmatic) question of whether it makes sense to treat employees irresponsibly, unfairly and inexpertlyin a bid to protect SEW (Berrone et al. 2012a, b; GómezMejía et al. 2014)_-if such an attitude can, in the longer run, jeopardise the very existence of the firm, thereby risking a loss of SEW? This again implies negative valence and contradiction.

Moreover, a desire to exert direct and permanent control over the entire organisation (in the name of "family control and influence") also appears to be at variance with modernday HRM thought, which highlights the significance and advocates the practice of empowerment, autonomy and participation (Green 2008; Heller et al. 1998; Zientara 2014). These conceptually related notions, while positively influencing staff behaviour, are about expanding (rather than restricting) employees' freedom in the workplace by granting them discretion over how they perform their tasks and a greater say in organisational decision-making. In other words, they are the antithesis of family owners' tendency to

\footnotetext{
3 The general consensus is that, pace calls for caution, the quality of the firm's HRM policy is positively related to its performance (Fleetwood and Hesketh 2006; Wall and Wood 2005).
}

centralize decision-making and wield ("top-down") control over every aspect of company operation. As highlighted earlier in the text, this manifests itself, too, in family owners' reluctance to hire outside executives and to delegate more power to non-family managers.

All this has two far-reaching implications. First, given the existence of the overlap between HRM and the employee dimension of CSR (Zientara 2014), it seems irrational and self-defeating to ignore HRM issues_also by "abating social practices related to internal stakeholders" (i.e. also as part of the firm's CSR policy) — as such conduct is likely to produce undesirable employee-level outcomes. Several psychological theories-most notably, social exchange theory (Cropanzano and Mitchell 2005), organismic integration theory (Ryan and Deci 2000) and social information processing theory (Salancik and Pfeffer 1978)—go some way towards explaining this phenomenon. For example, social information processing theory, which holds that the social environment wherein individuals operate influences their attitudes, and organismic integration theory, which unpicks the mechanism of individual motivation through external stimuli, imply that unfair treatment and neglect must lead to an unmotivated and uncommitted workforce. It follows that if the family firm practices nepotism and discriminates against non-family employees (Burkart et al. 2003; Jaskiewicz et al. 2013) or if it fails to train its workforce (thus neglecting worker development), it cannot reasonably expect its employees to be satisfied, committed and engaged. And, as is well known, job satisfaction, organisational commitment and work engagement are key attitudes, which not only determine employee behaviour in the workplace, but are also positively associated with a wide array of firmlevel outcomes (Bakker et al. 2011; Cegarra-Leiva et al. 2012; Kirkman and Shapiro 2001; Meyer and Allen 1991; Mowday et al. 1982).

Second and related, competent and responsible management of human resources can effectively ameliorate the family owners' position and reputation-and hence SEW - as a result of its better performance relative to its direct competitors as well as positive (electronic) word-ofmouth publicity. In line with what has been argued earlier, satisfied and loyal employees are likely to project the positive image of the firm in social media, which, in turn, may attract potential job applicants and customers with a strong preference for socially responsible firms. It follows that economic success due to competent HRM can produce tangible socioemotional benefits for the family, which reiterates the importance of HRM for its firm's competitiveness and performance (arguably, the same can be said, toutes proportions gardées, about investment by family firms in R\&D; see also Gómez-Mejía et al. 2014).

But there is far more to this than that. One aspect of the overlap between corporate social responsibility and HRM 
has to do with the channels through which CSR impacts the way employees are managed. Employee involvement in CSR-inspired environmental initiatives is a case in point (Bohdanowicz and Zientara 2008; Bohdanowicz et al. 2011). In fact, when employees participate in "green" training-and extensive training is part of HPWS - or engage in hands-on eco-friendly activities (say, planting trees or recycling waste), they learn new things. In this way, employee human capital is developed (it should be noted that both training and worker development feature saliently in CSRHub's employee category, which is often used for assessing firms' commitment to CSR). It is, therefore, clear that employee development occupies a prominent position both in HRM and CSR.

Moreover, given that the environmental dimension of CSR entails, as a rule, implementation of environmental management practices, it is now acknowledged that effective EM requires interaction with human resource management (Paillé et al. 2014; Wehrmeyer 1996). In other words, HRM is increasingly seen to play an important part in improving the firm's environmental performance (Bohdanowicz et al. 2011; Daily et al. 2012; Jackson and Seo 2010; Jackson et al. 2012; Paillé et al. 2014; Wehrmeyer 1996). This, in turn, has given rise to the term "green human resource management" (Jackson et al. 2011; Renwick et al. 2013), which implies, among other things, that organisations should employ HR practices to engage employees in pro-environmental behaviours. And there is widespread agreement that these behaviours need to be discrete (which suggests that employees are not forced-by immediate supervisors and/or concrete stipulations in their contracts-to act). That conceptually has to do with organisational citizenship behaviours (OCB) in general and organisational citizenship behaviours for the environment (OCBE) in particular (Paillé et al. 2014). The latter are defined as "discretionary acts by employees within the organisation not rewarded or required that are directed toward environmental improvement" (Daily et al. 2009, p. 246). The same logic extends to CSR. As the above example shows, it is indeed (low-ranking) employees who engage in OCB and de facto implement most CSR projects: they not only plant trees or recycle waste, but also participate in assorted activities aimed at helping local communities (for example, they volunteer in local old people's homes).

Accordingly, the success of the firm's CSR-inspired environmental efforts depends, to a large extent, on its capacity to voluntarily involve its employees who, accordingly, need encouragement and support. ${ }^{4}$ What is required, therefore, is an organisational climate that is

\footnotetext{
${ }^{4}$ Also worth mentioning is the sustainable development-stakeholder relations management approach (Pérez and Rodríguez del Bosqu, 2014), which emphasises the role managing stakeholders (with employees to the fore) plays in achieving sustainable development goals.
}

supportive of active environmental engagement (in practice, such a climate is underpinned by perceived organisational support and perceived supervisor support; Paillé et al. 2014). This is vital since, by and large, "when employees perceive that their organisation provides a supportive, involving, and challenging climate [...], they are more likely to respond by investing time and energy and by being psychologically involved in the work of their organization" (Bakker et al. 2011, p. 13). The implication is that "a company can devastate its efforts to become environmentally responsible if there is little or no support to train and encourage its employees to "do the right thing" (Govindarajulu and Daily 2004, p. 336).

In this context, the question arises of how to reconcile these insights with the tendency of the family firms, as documented by Cruz et al. (2014), to behave irresponsibly towards their workforces. Arguably, this is hardly conducive to the creation of a climate that is supportive of any organisational citizenship behaviours. It follows that it is problematic and inconsistent to expect employees who are treated irresponsibly to voluntarily engage in socially responsible actions and environmental management initiatives (oriented towards external stakeholders) (Neubaum et al. 2012). All that, again, suggests contradictions and negative valence to the SEW dimensions. At the same time, these contradictions also imply failure to recognise that HRM cannot be divorced both from CSR-inspired environmentalism (Wehrmeyer, 1996) and ethics (Greenwood, 2013).

\section{Conclusive Remarks}

This paper, drawing on Kellermanns et al.'s (2012) claim that the SEW dimensions can be negatively and positively valenced, has sought to provide a theoretical underpinning in favour of the view that SEW, in essence, has ambiguous and contradictory nature, leading to harmful outcomes for stakeholders of family firms. In this way, it has aimed to challenge the assumption predominant in the literature that SEW is "a prosocial and positive stimulus". In particular, the paper has argued that, given its ambivalent, "doublevalenced" nature, SEW is at odds with the "strategic, whole-business view of responsibility", which means that family firms-because of their concern with SEW-may be more likely to adopt the instrumental and selective rather than holistic and normative approach to CSR. In other words, family firms may be more likely to treat CSR instrumentally, with a view to obtaining - in the name of SEW-various self-interested "gains" rather than as a centrepiece of the strategy that reflects their concern with the wider social good. Seen in this way, CSR acts as a (public relations) tool with which to promote the family firm's interests while SEW becomes a driver of self-serving 
behaviour. Accordingly, the paper, by advocating the holistic and normative view of responsibility, has also postulated that it should serve as a reference point to explore any firm's stance on CSR.

More specifically, the paper, while explaining why the SEW dimensions can be negatively valenced, has identified a number of inherent contradictions related to the SEW view. These can be summarised as follows:

(1) While it might well be true that any enterprise- - be it family or non-family one-can carry out socially responsible practices related to external stakeholders and, simultaneously, act irresponsibly towards internal stakeholders, it is family firms that are more likely to do so due to concern with SEW and its ambiguous nature. Therefore, SEW, underpinning discriminatory behaviour towards non-family employees (non-family internal stakeholders) cannot be seen as an unequivocally prosocial and positive incentive since the family firm's staff are also members of society and, as such, merit fair treatment (on a par with its external stakeholders, such as customers and inhabitants of local communities). Equally importantly, family firms' tendency to cherry-pick only those CSR initiatives that are deemed to serve their own interests is at odds with the claim that CSR is about "actions that appear to further the social good, beyond the interest of the firm". Accordingly, SEW, being a de facto driver of self-serving behaviour, somehow degrades the character of CSR as a true force for societal advancement.

(2) Because of the need to protect SEW, family firms are particularly concerned with its image and reputation (as they see the business as an extension of the family name), which makes them likely to be more responsive to the demands of external rather than internal stakeholders. This fixation on image is not only likely to lead family firms to adopt the instrumental and selective approach to CSR, but also rests on the mistaken assumption that a company's external image hinges on how it treats its external stakeholders. Indeed, nowadays any firm's image and reputation can also be tarnished by irresponsible behaviour vis-à-vis its internal stakeholders (who, to reiterate, tend to expose and criticise online their employers' irresponsible or incompetent conduct). In fact, thanks to social media, behaving irresponsibly towards either external or internal stakeholders usually tarnishes the company's reputation. And there are examples of unfair or unprofessional employee treatment which has damaged, or at least sullied, the "external image" of a firm even if it behaves responsibly in other areas of CSR. In this sense, given that now corporate behaviour in its entirety is under intense public scrutiny, it is hardly warranted to differentiate between the "external" and "internal" image. Rather, there is a single company image which is bound to suffer as a result of irresponsible conduct; (3) In view of the link between the quality of the firm's HRM and its competitiveness as well as the overlap between HRM and the employee dimension of CSR, family firms' tendency to behave irresponsibly vis-àvis their (non-family) employees-in the name of SEW and as a result of the adoption of the selective and instrumental approach to CSR-is fraught with contradictions. Worker development in general and training provision in particular feature prominently both in the HRM and CSR narratives: they form part of high-performance work systems and, simultaneously, constitute socially responsible actions, as confirmed by the contents of CSRHub's employee category. Does irresponsible conduct towards their employees (internal stakeholders) suggest, therefore, that family firms pursue self-defeating policy? After all, unprofessional HRM practice or unfair behaviour towards employees threaten - by decreasing competitiveness and affecting performance in the longer run-the very survival of the firm (hence a total loss of SEW). Conversely, responsible and competent treatment of human resources is likely, all else being equal, to improve the family owners' position and reputation (through enhanced competiveness and positive word of mouth), which, in turn, brings socioemotional benefits to the family, thereby buttressing SEW.

(4) Considering that any firm's human resources are its greatest assets and a source of competitive advantage, family owners' reluctance to hire outside directors, to empower non-family managers and to give all (nonfamily) employees a greater say in organisational decision-making - in the name of the "family control and influence dimension" of SEW - can have dire firm-level consequences. The unwillingness to draw on outsiders' potential matters in particular in an era of global war for talent whereby companies vie with each other for most talented individuals. Therefore, a decision to forgo high skilled individuals who increasingly pay attention to how their future employer treats the stakeholders may-again—affect the family firm's chances of survival. This, in turn, might end up ultimately harming the family.

(5) Given that family firms' focus on their "image and reputation" in the outside world (as a way to protect SEW), they are loath to be stigmatised as irresponsible corporate citizens. Hence, to project the image 
of environmental responsibility, in the first place family firms need to practice environmental management. Yet this is unfeasible without active and voluntary involvement of low-ranking (non-family) employees (Bohdanowicz et al. 2011; Jackson et al. 2011; Paillé et al. 2014; Renwick et al. 2013; Wehrmeyer 1996). But how can one expect employees who are treated irresponsibly and unprofessionally to engage in organisational citizenship behaviours and, accordingly, to carry out socially and environmentally responsible initiatives? In other words, it is inconsistent and unworkable to seek to be seen -in the name of the "image and reputation" dimension of SEW - as an exemplary green corporate citizen and, at the same time, to behave irresponsibly towards one's employees (whose involvement is key to the success of any environmental programme).

All these contradictions and inconsistencies undermine the claim that SEW has positive nature. They imply, too, certain blindness to its "dark side" (Kellermanns et al. 2012) on the part of family members. Very often family owners perceive actions undertaken with the particular SEW dimensions in mind as a gain in SEW, somehow not seeing that they might eventually lead to a total loss of SEW (thereby being detrimental to the family itself). Furthermore, SEW, eliciting both "socially responsible and irresponsible behavior" in family firms (Cruz et al. 2014, p. 1310), is at variance with-and, from a certain perspective, irreconcilable with - the holistic and normative approach to CSR, which, in principle, rules out such "schizophrenic" conduct. When CSR becomes a core value and a central part of the strategy, being "socially responsible and irresponsible" at the same time is simply inconceivable. The experience of Scandic, which, however, not a family firm, bears that assertion out (Bohdanowicz and Zientara 2008). Indeed, it shows what it means, in practice, to adopt the holistic and normative approach to CSR.

Therefore, this study also offers wider implications for research on CSR in both family and non-family companies. Above all, while assessing any firm's engagement in CSR, it is advisable to look "under the skin" of the organisation and to appropriately interpret certain facts. Some scholars tend to regard participation in certification schemes, with eco-labels to the fore, as an indicator of environmental responsibly. ${ }^{5}$ In principle, this seems uncontroversial, yet it

\footnotetext{
5 It is worth noting that "Certification is awarded to businesses or activities that comply with a set of standards and generally requires more than what legal regulations do. [...] Labelling, which occurs through giving an ecolabel, is an award that is given to a business or activity that has significantly better performance compared to the other businesses in its sector" (Graci and Dodds 2015, p. 200).
}

is perfectly possible for a firm "to have a CSR strategy—or not to have a formal policy but to act in a highly responsible manner-and yet not to (want to) participate in certification schemes: in other words, willingness to participate in accreditation is not a criterion of, or a pre-requisite for, a business to behave (more) responsibly" (Coles et al. 2013, p. 127). This is because "like eco-labels, certification is an institutional device, practically as a membership scheme that recognises certain sets of activities for those who are eligible and apply" (ibid., p. 127). Furthermore, CSR reports often indicate, say, how many employees (as a percentage of the total workforce) volunteer to work for the needy in the local community, but they fail to specify whether staff are given paid time off for the volunteering or not (which is indicative of how committed to CSR the firm is).

Crucially, many companies explicitly declare that CSR is a core value and hence constitutes a centrepiece of their strategies. Such grandiose statements often feature saliently in official documents and on corporate websites, giving the impression that the businesses in question embrace the whole-business philosophy (which is appreciated by a growing number of socially conscious individuals who are increasingly allergic to public relations narratives in general and greenwash in particular). Yet, under closer scrutiny, it may turn out that the way those companies practise CSR hallmarks the instrumental and selective approach. This is because, as the example of Scandic shows (Bohdanowicz and Zientara 2008), turning CSR into a core part of the strategy is a veritable challenge that entails reprioritisation of corporate policies, instigation of a new organisational climate and implementation of (revolutionary) changes to the way a firm operates, especially in the area of human resource management and supply chain management (for example, "to avoid contributing to deforestation, Unilever already buys all its palm oil [...] through an audited sustainability scheme, and by 2020 it plans to buy it from certified and traceable sources"; Economist 2015c, p. 54).

Thus, what is needed is verification of those grandiose claims. In particular, when it comes to family businesses, that can be done by conducting in-depth interviews with family owners as well as, crucially, with low-ranking employees. The former should be asked about how they conceptualize CSR and whether, in reference to the "dark side" of SEW, they see links between broadly understood employee treatment and several firm-level variables, including performance, competitiveness and reputation. The latter, by contrast, should be asked about whether they function in a social milieu that is supportive of OCB(E) and whether they feel supported in their CSR-inspired (environmental) activities by their supervisors and the organisation. Such interviews should allow researchers to find out whether, in fact, the companies under consideration hold 
the strategic, whole-business view of responsibility or rather the instrumental and selective approach. And this, as has been argued throughout the text, is of key importance as the former appears to be a real force for the wider social good. It is hoped that this paper will prompt both debate and research on SEW and its impact on the practice of CSR.

\section{Compliance with Ethical Standards}

Disclosure statement I declare that this study was not funded by any grant. I also declare that I have no potential conflict of interest.

Open Access This article is distributed under the terms of the Creative Commons Attribution 4.0 International License (http://crea tivecommons.org/licenses/by/4.0/), which permits unrestricted use, distribution, and reproduction in any medium, provided you give appropriate credit to the original author(s) and the source, provide a link to the Creative Commons license, and indicate if changes were made.

\section{References}

Adams, J. S., Taschian, A., \& Shore, T. H. (1996). Ethics in family and non-family owned firms: An exploratory study. Family Business Review, 9(2), 157-170.

Aguilera, R. V., Rupp, D. E., Williams, C. A., \& Ganapathi, J. (2007). Putting the $\mathrm{S}$ back in corporate social responsibility: A multilevel theory of social change in organisations. Academy of Management Review, 32(3), 836-863.

Albinger, H., \& Freeman, S. (2000). Corporate social performance and attractiveness as an employer to different job seeking populations. Journal of Business Ethics, 28(3), 243-253.

Albrizio, S., Botta, E., Kozluk, T., \& Zipperer, V. (2014). Do environmental policies matter for productivity growth?. OECD, Paris: Insights from new cross-country measures of environmental policies.

Armstrong, M. (2009). Armstrong's handbook of human resource management practice. London: Kogan Page Limited.

Bakker, A. B., Albrecht, S. L., \& Leiter, M. P. (2011). Key questions regarding work engagement. European Journal of Work and organisational Psychology, 20(1), 4-28.

Barney, J. B. (1991). Firm resources and sustained competitive advantage. Journal of Management, 17(1), 99-120.

Barney, J. B., \& Hesterly, W. S. (2008). Strategic management and competitive advantages. Upper Saddle River, NJ: Pearson Prentice Hall.

Barney, J., Wright, M., \& Ketchen, D. J, Jr. (2001). The resourcebased view of the firm: Ten years after 1991. Journal of Management, 27(6), 625-641.

Baron, D. (2001). Private politics, corporate social responsibility, and integrated strategy. Journal of Economics and Management Strategy, 10(1), 7-45.

Barrett, L. F. (1996). Hedonic tone, perceived arousal and item desirability: Three components of self-reported mood. Cognition and Emotion, 10(1), 47-68.

Berrone, P., Bennamo, C., Cruz, C., \& Gómez-Mejía, L. R. (2012a). Socioemotional wealth and proactive stakeholder engagement: Why family controlled firms care more about their stakeholders. Entrepreneurship Theory \& Practice, 36(6), 1153-1173.

Berrone, P., Cruz, C., \& Gómez-Mejía, L. R. (2012b). Socioemotional wealth in family firms: Theoretical dimensions, assessment approaches and agenda for future research. Family Business Review, 25(3), 258-279.

Bingham, J. B., Dyer, W. G., Jr., Smith, I., \& Adams, G. L. (2011). A stakeholder identity orientation approach to corporate social performance in family firms. Journal of Business Ethics, 99(4), $565-585$.

Blowfield, M., \& Murray, A. (2011). Corporate responsibility. Oxford: Oxford University Press.

Bohdanowicz, P., \& Zientara, P. (2008). Corporate social responsibility in hospitality: Issues and implications. A case study of Scandic. Scandinavian Journal of Hospitality and Tourism, 8(4), 271-293.

Bohdanowicz, P., \& Zientara, P. (2012). CSR-inspired environmental initiatives in top hotel chains'. In D. Leslie (Ed.), Tourism enterprises and the sustainability agenda across Europe (pp. 93-120). Farnham: Ashgate.

Bohdanowicz, P., Zientara, P., \& Novotna, E. (2011). International hotel chains and environmental protection: Analysis of Hilton's we care! programme (Europe, 2006-2008). Journal of Sustainable Tourism, 19(7), 797-816.

Burkart, M., Panunzi, F., \& Shleifer, A. (2003). Family firms. The. Journal of Finance, 58(5), 2167-2202.

Cacioppe, R., Forster, N., \& Fox, M. (2008). A survey of managers' perceptions of corporate ethics and social responsibility and actions that may affect companies' success. Journal of Business Ethics, 82(3), 681-700.

Camilleri, M. (2014). Advancing the sustainable tourism agenda through strategic CSR perspectives. Tourism Planning \& Development, 11(1), 42-56.

Carvalho, S. W., Sen, S., de Oliveira Mota, M., \& de Lima, R. C. (2010). Consumer reactions to CSR: A Brazilian perspective. Journal of Business Ethics, 91(2), 291-310.

Cegarra-Leiva, M., Sánchez-Vidal, E., \& Cegarra-Navarro, J. G. (2012). Work life balance and the retention of managers in Spanish SMEs. International Journal of Human Resource Management, 23(1), 91-108.

Cennamo, C., Berrone, P., Cruz, C., \& Gómez-Mejía, L. R. (2012). Socioemotional wealth and proactive stakeholder engagement: Why family controlled firms care more about their stakeholders. Entrepreneurship: Theory and Practice, 36(6), 1153-1173.

Chandler, D. B., \& Werther, W. B. (2014). Strategic corporate social responsibility: Stakeholders, globalization, and sustainable value creation. Thousand Oaks: SAGE.

Chrisman, J. J., Chua, J. H., Pearson, A. W., \& Barnett, T. (2012). Family involvement, family influence, and family-centered noneconomic goals in small firms. Entrepreneurship Theory and Practice, 36(2), 267-293.

Chua, J. H., Chrisman, J. J., \& Bergiel, E. B. (2009). An agency theoretic analysis of the professionalized family firm. Entrepreneurship Theory and Practice, 33(2), 355-372.

Coles, T., Fenclova, E., \& Dinan, C. (2013). Tourism and corporate social responsibility: A critical review and research agenda. Tourism Management Perspectives, 6, 122-141.

Collins, C. J., \& Smith, K. G. (2006). Knowledge exchange and combination: The role of human resource practices in the performance of high-technology firms. Academy of Management Journal, 49(3), 544-560.

Cooper, I. (1998). Emerging issues in environmental management. In K. Alexander (Ed.), Facility management: Theory and practice (pp. 111-119). London: Spon Press.

Corbetta, G., \& Salvato, A. (2004). Self-serving or self-actualizing? Models of man and agency costs in different types of family firms: A commentary on "Comparing the agency costs of family and non-family firms: Conceptual issues and exploratory evidence." Entrepreneurship Theory and Practice, 28(4), $355-362$. 
Cropanzano, R., \& Mitchell, M. S. (2005). Social exchange theory: An interdisciplinary review. Journal of Management, 31(6), 874-900.

Cruz, C., Larraza-Kintana, M., Garcés-Galdeano, L., \& Berrone, P. (2014). Are family firms really more socially responsible? Entrepreneurship: Theory and Practice, 38(6), 1295-1316.

Daily, B. F., Bishop, J. W., \& Govindarajulu, N. (2009). A conceptual model for organisational citizenship behavior directed toward the environment. Business and Society, 48(2), 243-256.

Daily, B. F., Bishop, J. W., \& Massoud, J. A. (2012). The role of training and empowerment in environmental performance: A study of the Mexican maquiladora industry. International Journal of Operations \& Production Management, 32(5), 631-647.

Davis, J. H., Schoorman, F. D., \& Donaldson, L. (1997). Toward a stewardship theory of management. Academy of Management Review, 22(1), 20-47.

Deephouse, D. L., \& Jaskiewicz, P. (2013). Do family firms have better reputations than non-family firms? An integration of socioemotional wealth and social identity theories. Journal of Management Studies, 50(3), 337-360.

De Kok, J. M. P., Uhlaner, L. M., \& Thurik, A. R. (2006). Professional HRM practices in family owned-managed enterprises. Journal of Small Business Management, 44(3), 441-460.

Déniz-Déniz, D., \& Cabrera-Suárez, M. K. (2005). Corporate social responsibility and family business in Spain. Journal of Business Ethics, 56(1), 59-71.

Dyer, W. G., \& Whetten, D. A. (2006). Family firms and social responsibility: Preliminary Evidence from the S\&P 500. Entrepreneurship: Theory and Practice, 30(6), 785-802.

Economist. (2014a, 30 August). A new green wave, 412(8902), p. 53.

Economist. (2014b, 1 November). Relative success, 413(8911), pp. 11-12.

Economist. (2015a, 28 February). Brazil's business Belindia, 414(8927), p. 60.

Economist. (2015b, 10 January). Enforcing with a smile, 414(8920), p. 49.

Economist. (2015c, 6 June). Walking the walk, 415(8941), pp. 54-55. Economist. (2015d, , 6 June). Winds of change, 415(8941), pp. 51-53.

Environmental Performance Index (2015). Country rankings. Retrieved January 9, 2015, from http://epi.yale.edu/epi/countryrankings/.

Fleetwood, S., \& Hesketh, A. (2006). HRM-performance research: Under-theorised and lacking explanatory power. International Journal of Human Resources Management, 17(12), 1979-1995.

Font, X., Walmsley, A., Cogotti, S., McCombes, L., \& Hausler, N. (2012). Corporate social responsibility: The disclosure-performance gap. Tourism Management, 33, 1544-1553.

Freeman, E. (1984). Strategic management: A stakeholder approach. Boston: Pitman.

Garay, L., \& Font, X. (2012). Doing good to do well? Corporate social responsibility: reasons, practices and impacts in small and medium accommodation enterprises. International Journal of Hospitality Management, 31(2), 329-337.

Gazeta Wyborcza. (2015). Black list of employers on Facebook. Retrieved January 28, 2015, from http://wyborcza.pl/10,82983, 17313691,Czarna_lista_pracodawcow_na_Facebooku_.html/.

Gedajlovic, E., Carney, M., Chrisman, J. J., \& Kellermanns, F. W. (2012). The adolescence of family firm research: Taking stock and planning for the future. Journal of Management, 38(4), $1010-1037$.

Gómez-Mejía, L. R., Tochman Campbell, J., Martin, G., Hoskisson, R. E., Makri, M., \& Sirmon, D. G. (2014). Socioemotional wealth as a mixed gamble: Revisiting family firm R\&D investments with the behavioural agency model. Entrepreneurship: Theory and Practice, 38(6), 1351-1374.
Govindarajulu, N., \& Daily, B. F. (2004). Motivating employees for environmental improvement. Industrial Management \& Data Systems, 104(4), 364-372.

Graci, S., \& Dodds, R. (2015). Certification and labeling. In C. M. Hall, S. Gössling, \& D. Scott (Eds.), The Routledge handbook of tourism and sustainability (pp. 200-208). Abingdon: Routledge.

Green, F. (2008). Leeway for the loyal: A model of employee discretion. British Journal of Industrial Relations, 46(1), 1-32.

Greening, D. W., \& Turban, D. B. (2000). Corporate social performance as a competitive advantage in attracting a quality workforce. Business and Society, 39(3), 254-280.

Greenwood, M. (2013). Ethics and HRM: A review and conceptual analysis. Journal of Business Ethics, 114(2), 355-366.

Guest, D. (1997). Human resource management and performance: A review and research. International Journal of Human Resource Management, 8(3), 263-276.

Gursoy, D., Chi, C. G., \& Karadag, E. (2013). Generational differences in work values and attitudes among frontline and service contact employees. International Journal of Hospitality Management, 32, 40-48.

Heller, F., Pusić, E., Strauss, G., \& Wilpert, B. (1998). organisational participation: Myth and reality. New York: Oxford University Press.

Hillenbrand, C., Money, K., \& Ghobadian, A. (2013). Unpacking the mechanism by which corporate responsibility impacts stakeholder relationships. British Journal of Management, 24(1), 127-146.

Holcomb, J. L., Upchurch, R. S., \& Okumus, F. (2007). Corporate social responsibility: What are the top hotel companies reporting? International Journal of Contemporary Hospitality Management, 19(6), 461-475.

Jackson, S. E., Ones, D. S., \& Dilchert, S. (2012). Managing human resource for environmental sustainability. San Francisco: Jossey-Bass.

Jackson, S. E., Renwick, D. W. S., Jabbour, C. J. C., \& MullerCamen, M. (2011). State-of-the-art and future directions for green human resource management: Introduction to the special issue. Zeitschrift für Personalforschung, 25(2), 99-116.

Jackson, S. E., \& Seo, J. (2010). The greening of strategic HRM scholarship. organisation Management Journal, 7(4), 278-290.

Jaskiewicz, P., Uhlenbruck, K., Balkin, D. B., \& Reay, T. (2013). Is nepotism good or bad? Types of nepotism and implications for knowledge management. Family Business Review, 26(2), 121-139.

Kellermanns, F. W., Eddleston, K. A., \& Zellweger, T. (2012). Extending the socioemotional wealth perspective: A look at the dark side. Entrepreneurship Theory and Practice, 36(6), $1175-1182$.

Kirkman, B., \& Shapiro, D. (2001). The impact of cultural values on job satisfaction and organisational commitment in self-managing work teams: The mediating role of employee resistance. Academy of Management Journal, 44(3), 557-569.

Kotonen, U. (2009). Formal corporate social responsibility reporting in Finnish listed Companies. Journal of Applied Accounting Research, 10(3), 176-207.

Lado, A. A., \& Wilson, M. (1994). Human resource systems and sustained competitive advantage: A competence based perspective. Academy of Management Review, 19(4), 699-727.

Lee, M.-D. P. (2008). A review of the theories of corporate social responsibility: Its evolutionary path and the road ahead. International Journal of Management Review, 10(1), 53-73.

Lee, T. H., Jan, F.-H., \& Huang, G. W. (2015). The influence of recreation experiences on environmentally responsible behavior: the case of Liuqui Island, Taiwan. Journal of Sustainable Tourism, 23(6), 947-967. 
Lim, A., \& Tsutsui, K. (2012). Globalization and commitment in corporate social responsibility cross-national analyses of institutional and political-economy effects. American Sociological Review, 77(1), 69-98.

Luo, X., \& Bhattacharya, C. B. (2006). Corporate social responsibility, customer satisfaction, and market value. Journal of Marketing, 70(4), 1-18.

Makadok, R. (2001). Toward a synthesis of the resource-based view and dynamic-capability views of rent creation. Strategic Management Journal, 22(5), 387-401.

Marques, P., Presas, P., \& Simon, A. (2014). The heterogeneity of family firms in CSR engagement: The role of values. Family Business Review, 27(3), 206-227.

Mayer, R. C. (2013). Firm commitment. Why the corporation is failing us and how to restore trust in it. Oxford: Oxford University Press.

McWilliams, A., \& Siegel, D. (2001). Corporate social responsibility: A theory of the firm perspective. Academy of Management Review, 26(1), 117-127.

Meyer, J. P., \& Allen, N. J. (1991). A three-component conceptualization of organisational commitment. Human Resource Management Review, 1(1), 61-89.

Mitchell, R. K., Agle, B. R., Chrisman, J., \& Spence, L. J. (2011). Toward a theory of stakeholder salience in family firms. Business Ethics Quarterly, 21(2), 235-255.

Morck, R., \& Yeung, B. (2003). Agency problems in large family business groups. Entrepreneurship Theory and Practice, 27(4), 367-382.

Mowday, R. T., Porter, L. W., \& Steers, R. M. (1982). organisational linkages: The psychology of commitment, absenteeism, and turnover. San Diego: Academic Press.

Neubaum, D. O., Dibrell, C., \& Craig, J. B. (2012). Balancing natural environmental concerns of internal and external stakeholders in family and non-family businesses. Journal of Family Business Strategy, 3(1), 28-37.

O’Boyle, E. H., Jr., Rutherford, M. W., \& Pollack, J. M. (2010). Examining the relation between ethical focus and financial performance in family firms: An exploratory study. Family Business Review, 23(4), 1-17.

Paillé, P., Chen, Y., Boiral, O., \& Jin, J. (2014). The impact of human resource management on environmental performance: An employee-level study. Journal of Business Ethics, 121(3), 451-466.

Peterson, D. K. (2004). The relationship between perceptions of corporate citizenship and organizational commitment. Business and Society, 43(3), 296-319.

Pérez, A., \& Rodríguez del Bosque, I. (2014). Sustainable development and stakeholders: A renew proposal for the implementation and measurement of sustainability in hospitality companies. Knowledge and Process Management, 21(3), 198-205.

Porter, M. \& Kramer, M.R. (2006, December). Strategy and society: the link between competitive advantage and corporate social responsibility. Harvard Business Review, pp. 78-89.

Porter, M. \& Kramer, M.R. (2011, January-February). Creating shared valu. Harvard Business Review, pp. 62-77.

Porter, L. W., Steers, R. M., Mowday, R. T., \& Boulian, P. W. (1974). organisational commitment, job satisfaction, and turnover among psychiatric technicians. Journal of Applied Psychology, 59, 603-609.

Renwick, D. W. S., Redman, T., \& Maguire, S. (2013). Green human resource management: A review and research agenda. International Journal of Management Reviews, 15(1), 1-14.
Rodriguez, P., Siegel, D., Hillman, A., \& Eden, L. (2006). Three lenses on the multinational enterprise: Politics, corruption, and corporate social responsibility. Journal of International Business Studies, 37(6), 733-746.

Ryan, R. M., \& Deci, E. L. (2000). Self-determination theory and the facilitation of intrinsic motivation, social development, and wellbeing. American Psychologist, 55(1), 68-78.

Salancik, G. J., \& Pfeffer, J. (1978). A social information processing approach to job attitudes and task design. Administrative Science Quarterly, 23, 224-253.

Scandic (2014b) Code of conduct. Retrieved February 2, 2014, from http://www.scandichotels.com/settings/Side-foot/About-us-Con tainer/About-Scandic/Code-of-conduct/.

Scott, D. (2011). Why sustainable tourism must address climate change. Journal of Sustainable Tourism, 19(1), 17-34.

Sharma, P. (2006). An overview of the field of family business studies: Current status and directions for the future. In P. Z. Poutziouris, K. X. Smyrnious, \& S. B. Klein (Eds.), Handbook of research on family business (pp. 25-55). Cheltenham: Edward Elgar.

Stavrou, E., Kassinis, G., \& Filotheou, A. (2007). Downsizing and stakeholder orientation among the Fortune 500: Does family ownership matter?. Journal of Business Ethics, 72(2), 149-162.

Stites, J. P., \& Michael, J. H. (2011). organisational commitment in manufacturing employees: Relationships with corporate social performance. Business and Society, 50(1), 50-70.

Takeuchi, R., Chen, G., \& Lepak, D. P. (2009). Through the looking glass of a social system: Cross-level effects of high performance work systems on employees' attitudes. Personnel Psychology, $62(1), 1-29$

Thornton, J. C., \& Byrd, J. T. (2013). Social responsibility and the small business. Academy of Entrepreneurship Journal, 19(1), $41-75$.

Vaaland, T. I., Heide, M., \& Gronhaug, K. (2008). Corporate social responsibility: Investigating theory and research in the marketing context. European Journal of Marketing, 42(9/10), 927-953.

Wall, T., \& Wood, S. (2005). The romance of human resource management and business performance. Human Relations, 58(4), $429-462$

Weaver, D. (2011). Can sustainable tourism survive climate change? Journal of Sustainable Tourism, 19(1), 5-15.

Wehrmeyer, W. (1996). Greening people. Sheffield: Greenleaf Publishing.

Wijesinghe, G. (2014). Reimagining the application of sustainability to the hospitality industry through a virtue ethics framework. Journal of Sustainable Tourism, 22(1), 31-49.

Wood, D. J., \& Jones, R. E. (1995). Stakeholder mismatching: A theoretical problem in empirical research on corporate research performance. International Journal of Organizational Analysis, 3(3), 229-267.

Zellweger, T., Nason, R., Nordqvist, M., \& Brush, C. (2011). Why do family firms strive for nonfinancial performance? Entrepreneurship Theory and Practice, 37(2), 229-248.

Zientara, P. (2014). Human resource management in emerging economies. London: Routledge.

Zientara, P., Kujawski, L., \& Bohdanowicz-Godfray, P. (2015). Corporate social responsibility and employee attitudes: evidence from a study of Polish hotel employees. Journal of Sustainable Tourism, 23(6), 859-880. 